Dept. of Pathology,

Fac. Vet. Med., Assiut Univ.

\title{
VIRAL ENCEPHALOPATHY OF PIGEONS \\ IN ASSIUT GOVERNORATE
}

(With 10 Figures)

By

\section{MUBARAK and I.A.FOUAD*}

*Animal health research institute,Assiut lab. (Received at 28/3/2001)

$$
\begin{aligned}
& \text { الإعتلال المخي الفيزوسي في الحمام في محافظة أنسيوط } \\
& \text { محمد مبارك محمد ، الير/هبيم أحمد فؤ) عبه اللرانق }
\end{aligned}
$$

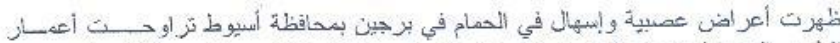

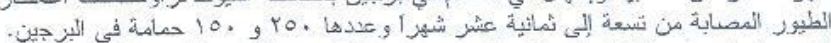

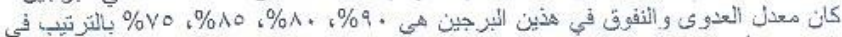

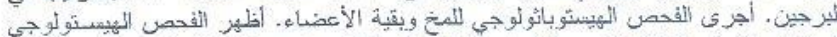

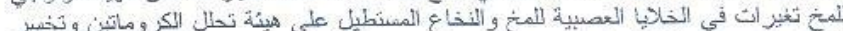

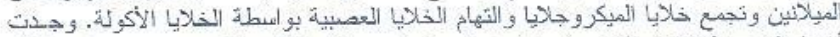

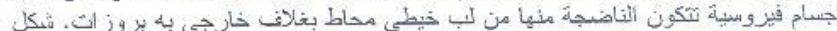

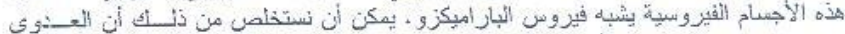

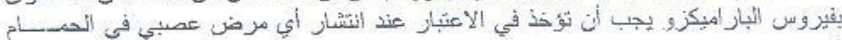

\section{SUMMARY}

Pigeons in two lofts ( $\mathrm{n}=250,150)$ aging 9-18 months in Assiu governorate manifested nervous signs and diarrhoea. Morbidity and mortality percentages in the affected two lofts were $90 \%, 80 \%$ and $85 \%$, $75 \%$, respectively. Histopathological examination of the brain tissues, in addition to other organs, of the infected pigeons was carried out. Therc was neuronal degeneration in the form of chromatolysis followed by microgliosis, demyelination, satellitosis and neuronophagia. These changes were observed in the mid-brain and brain stem. Mature viral particles were detected in the cytoplasm of neurons of the cerebral gray matter. Each viral particle was composed of filamentous core 
(nucleocapsids) and external enveloping membranes which had radiating projections (spikes). The morphology of the viral particle was similar to that of paramyxoviruses. It was concluded that paramyxovirus infection of pigeons in Egypt should be considered when a neurological disease is investigated.

Key words: Pigeon-encephalitis-paramyxovirus-pathology.

\section{INTRODUCTION}

Viruses which cause nervous manifestations in pigeons include herpesvirus (pigeon herpes encephalomyelitis virus, PHEV) and paramyxoviruses (Al Falluji et al., 1979; Tantawi et al., 1979; Al Sheikhly et al., 1980; Russel \& Alexander, 1983; Kaleta et al., 1985; Carranza et al.. 1986 and Wilson, 1986).

Avian-paramyxoviruses (PMVs) include 9 serotypes from PMV-1 to PMV-9 (Alexander, 1986). Although Newcastlc disease virus (NDV) (PMV-1) is the most important member, the other paramyxoviruses are also responsible for serious diseases (Alexander, 1997). In many countries, paramyxoviruses have been incriminated in the development of natural pigcon infections which are characterized by nervous signs (Kaleta et al., 1985; Mangat ct al., 1988; Hamson et al., 1989; Shakal, 1989; Barton et al., 1992; Berger, 1992; Duchatel et al., 1992; Kosters et al., 1992; Johnston \& Key, 1992; Al-Afaleq-Al et al., 1993; GurkirpalSingh, 1993 and PennycotL, 1994). Also, the nervous discase in pigeons has becn successfully induced by experimental infection of PMV (LIMubarak et al., 1990 and El-Sisi et al., 1995).

Pigeon paramyxovirus infection in Egypt was first reported by Avian Study Group (1984). The discase in Egypt was diagnosed for the first time as ND outbreak in pigeons (Ahmed and Redda, 1967). Mohammed et al. (1978) attributed a similar pigeon disease to herpesvirus. Later, Shakal (1989) identified the aetiological agent as PMV-1.

In Assiut and Sohag governorates paramyxovirus infection of pigeons was studied by Ibrahim et al. (2000). The virus was characterized by electron microscopy, haemagglutination $(\mathrm{HA})$ and haemagglutination inhibition $(\mathrm{HI})$ activities and polypeptide profiling. However, the described pathological picture was that of the inoculated 
chicken embryos. Therefore, the objective of the present study was to illustrate the morphopathological picture in the infected pigeons.

\section{MATERIALS and METHODS}

\section{Infected pigeons:}

Birds in two pigeon lofts $(n=250,150)$ aged $9-18$ months at Assiut governorate manifested nervous signs (poor balance, moving backwards and in circles, ataxia, torticollis and head tremors) and grcenish watery diarrhoea. The birds were inappetant and emaciated. Morbidity and mortality in the affected two lofts were $90 \%, 80 \%$ and $85 \%, 75 \%$, respectively,

\section{Gross pathology:}

Brain tissues and other visceral organs were examined for the existence of gross pathological changes.

\section{Histopathology:}

Brain tissues, in addition to other organs and tissues including liver, lungs, kidneys, heart, spleen and bursa obtained from freshly dead and sacrificed diseased pigeons were fixed in $10 \%$ neutral buffered formalin. Fixed tissues were processed routinely for paraffin embedding technique, sectioned at $3 \mu \mathrm{m}$ and stained with hematoxylin and cosin (HE) (Bancroft and Stevens, 1982).

Transmission electron microscopy:

Immediate fixation of the brain tissues ( $1 \mathrm{~mm}$ cubes) removed from infected birds was carried out by immersion in $4 \%$ buffered glutaraldehyde $\left(4^{\circ} \mathrm{C}\right)$. Fixed tissues were post-fixed in $1 \%$ osmium tetroxide, dehydrated in up-graded ethanol series and embedded in Fpon 812. Semi-thin sections stained with $1 \%$ toluidine blue were examined to localize the desired tissues. Consequently, ultra-thin sections were prepared, double staincd with uranyl acetate and lead citratc (Johannessen, 1978) and examined under transmission electron microscope (TEM) (JEOL $100 \mathrm{CXII}$ ) operated at $80 \mathrm{kv}$.

\section{RESULTS}

Gross findings:

No remarkable gross changes other than congestion were detected in the examined brain tissues. Also, other viscera were congested. Excess mucus was noticed on the intestinal mucosa. 


\section{Histopathology:}

Histological changes of the examined brain tissues were the most remarkable. These changes were represented by degenerative and necrotic changes of the neuronal cells in mid-brain and brain stem. Neuronal cells showed swelling, decreased density of Nissl's substance (chromatolysis), dispersion of the nuclear chromatin and peripheralization of the nuclei (Fig. 1). At some locations, there were also necrotic changes evidenced by nuclear pyknosis, cytoplasmic hypereosinophilia and cell shrinkage. Focal and diffuse reaction of glia cclls (microgliosis) were noticed (Fig. 2). Also, the reacting glia cells were seen surrounding the affected neurons (satellitosis) and this was associated with neuronophagia (Fig. 3).

In brain stem and corpus callosum, demyelination of nerve fibers was observed (Fig. 4). Lymphoid cell cuffs were seen surrounding the brain capillaries. Edema in the brain tissue was either pericellular or perivascular. Disorganization and chromatolysis were the prominent changes of Purkinje cells of the cerebellar cortex.

As regard to other tissues, interstitial lymphoid cell infiltration was observed in heart (Fig. 5), liver, kidneys (Fig. 6) and pancreas. The cellular infiltration was accompanied with parenchymal degencrative and necrotic changes in the corresponding tissucs.

\section{Transmission electron microscopy:}

Viral particles were detected in the cytoplasm of neurons in cerebral gray matter. The pleomorphic viral particles measured 130-160 $\mathrm{nm}$ in diameter. Each viral particle was composed of a core and enveloping membranes (Figs. $7 \& 8$ ). The nucleic core was in the form of central filamentous material and peripheral capsomercs (nucleo-capsids). Surface projections (spikes) (7-12 $\mathrm{nm}$ in length) gave a fringed appearance to the external membrane of the viral particles. Viral particles were also prsent within cytoplasmic vacuoles (Fig. 9). Some scattered immature viral particles, composed of nucleic core without enveloping membrane were also noticed. Some of the viral particles which had incomplete enveloping membrane represented degenerated viral forms. Budding viral forms were also observed in close association to cell membranes of the infected cells (Fig. 10). Certain segments of the cell membrane were of higher electron density and beared spikes similar to those of the viral particles. Mitochondria in the infected cells were apparently swollen. Free ribosomes were numerous and RFR was dilated with the presence of abundant amorphous material in their cisternac. 


\section{DISCUSSION}

The present study demonstrated that the infecting virus can produce pathological changes in brain tissues. In this respect, severe economic losses due to neurological signs and high mortality were reported in pigeons and other members of Cloumbidae family infected with avian paramyxoviruses (Lancaster and Alexander, 1975).

The observed pathological picture bears some similarities to that of NDV (PMV-1) infection (Alexander, 1997).

Absence of any noticeable gross lesions in the brain tissues of present cases are in line with the various reports on paramyxovirus infections (Barton et al., 1992; Johnston and Key, 1992). The observed histological changes in the brain tissues included neuronal degenerative changes, microglial reaction and demyelination. This picture is that of non-purulent encephalitis which conforms with that reported on paramyxovirus infections (Beard \& Easterday, 1967; Wilczynski ct al. 1977 and Beard \& Hanson, 1984).

As demonstrated by electron microscopy, the viral particles were only detected free in cytoplasm of the infected neuronal cells. This finding may indicate that replication of the infecting virus occurred only in cytoplasm as in case of other RNA-group of viruses (Holmes et al. 1969). Budding viral forms were also seen in the cxamined brain tissues. Configuration of the present infecting virus is identical to that reported in the recent study of Ibrahim et al. (2000) which dealt with similar cases. In the latter study the infecting viral particles were seen obviously budding from the infected neuronal cells of the inoculated chicken embryos. This may indicate the high infectivity of the examined virus.

The detected viral particles were built-up of filamentous core (nucleocapsid) and external envelope. The replication strategy of paramyxoviruses is based upon assembly of viral nucleocapsid in cytoplasm and thereafter acquirement of the external membranous coat by budding through cell plasma membrane (Holmes et al., 1969; Grimley \& Fricdman, 1970; Zlotnik \& Harris, 1970; Boulton \& Webb, 1971 and Whitefield et al., 1971). As illustrated here, the filamentous nucleocapsids of paramyxoviruses are usually aligned beneath the external envelope. Spikes (surface projections) appear on the outc surface of mature viral particles just before budding. Bricfly, the illustrated viral structure and the suggested assembly mode are in 
agrement with that reported on members of family Paramyxoviridac, genus Paramyxovirus (Finch \& Gibbs, 1970: Donelly \& Yunis, 1971: Mclean \& Doane, 1971; Cheville \& Beard, 1972; Seto et al., 1980 and Castleman, 1984).

Although outbreaks of herpesvirus encephalitis in pigeons were reported in Egypt by some workers (Mohammed et al., 1978; Tantawi ct al., 1979; Tantawi \& Hassan, 1982 and $\mathrm{Abd}$-El-Motelib et al., 1994), no evidence of herpesvirus infection was recognized presently. The present virus morphology is different from that of herpesvirus and the intranuclear inclusions in neuronal cells of cerebellar cortex diagnostic $f$ orherpesvirus infection (Carranza et al., 1986 and Christopher et al., 1993) were not detected. Recently, the incidence of outbreaks of paramyxovirus infection in pigeons was increased. In one of the most recent studies (Aly, 2000) 20 isolates of paramyxoviruses were recovered from 40 pigeon outbreaks.

Conclusively, the role of paramyxoviruses in causation of nervous diseases in pigeons should be considered together with the other suspected viruses such as herpesvirus. Isolates of PMV-1 infecting pigeons were found highly pathogenic for chickens (Aly, 2000). Thus, it is reasonable to conclude that paramyxovirus infection of pigeons represents a great risk for chicken flocks as the infected pigeons may act as long-term disseminators.

\section{REFERENCES}

Abd-Fl-Motelib, T.Y.; El-Ballal. S.S. and Galal, B. (1994): Herpesvirus encephalitis in pigeons. Assiut Vet. Med. J., 60, 306-319.

Ahmed, A.A.S. and Reda, I.M. (1967): response of pigeons to cight strains of newcastle disease virus. Avian Dis., 11:1, 734-740.

Al Falluil, M.M. Al Sheikhly, F. and Tantawi, H.H. (1979): Viral encephalomyelitis of pigeons Pathology and virus isolation. Avian Dis, $23,777-784$.

Al Sheikhly, F.; Tantawi, H.H. and Al Falluji, M.M. (1980); Viral encephalomyelitis of pigeons. III Growth of the virus in embryonated eggs. Avian Dis., 24, 112-119.

Al-Afaleq-AI; Abu-Elzein, E.M.E; Gameel, A.A.; Awaad, M.; Hassanein, M.M. and Afaleq, A.I.A. (1993): A severe nervous discase in fancy pigeons caused by paramyxovirus-1 in Saud Arabia. Revue-d elevage-et-de-Medecine-Veterinaire-des-PaysTropicaux, 46, 545-547. 
Alexander, D.J. (1986). The classification, host range and distribution on avian paramyxoviruses. In: Acutc Virus Infections of Poultry, J.B. McFerran \& M.S. McNulty (Eds.). pp. 52-66. Martinus Nijhoff, Dordrecht (Netherlands).

Alexander, D.J. (1997): Newcastle disease and other avian paramyxoviridac infections In: Diseases of Poultry. M.S Hofstad, H.7. Barnes, B.W. Calnck, W.M. Reid. and II.W. Yoder (Eds.) 10th Edn. pp. 541-569. Iowa State Univ. Press. (Ames, Iowa).

Aly, $M$. (2000): Epidemiological and immunological studies on avian paramyxovirus infection in pigeons. Tth Sci. Con., 2000. Faculty of Vet. Med., Assiut Univ., Egypt.

Avian study group (1984): Paramyxovirus infection of pigeon. Vet. Rec., $114: 232$.

Bancroft, D. and Stevens, A. (1982): Theory and Practice of Histological Techniques. 2nd Edn. Churchill Livingstone (Edinburgh, London, Melbourne).

Barton, J.T.; Bickford, A.A.; Cooper, G.L.; Charlton, B.R. and Cardona, C.J. (1992): Avian paramyxovirus type 1 infections in racing pigeons in California. 1 . Clinical signs, pathology, and serology. Avian Dis, , 36, 463-468.

Beard, C.W. and Easterday, B.C. (1967): The influence of route of administration of Newcastle disease virus on host response. $J$. Infect. Dis., 117, 55-70.

Beard, C.W. and Hanson, R.P. (1984). Newcastle disease. In : Diseases of Poultry. M.S. Hofstad, H.J Barnes, B.W. Calnek, W.M. Reid \& H.W. Yoder (Eds.) 8th ed. PP. 425-470. Towa State Univ. Press, Ames.

Berger, R. (1992): Paramyxovirus type 1 in pigeons in Finland. BulletinOffice-International-des-Lpizooties, 104,915.

Boulton, P.S. and Webb, H.E. (1971): An electron microscopic study of langat virus encephalitis in mice. Brain, 94, 411.

Carranza, J.; Poveda, J.B and Fernandez, A. (1986): An outbreak of encephalitis in pigeons (Columba livia) in the Canary islands (Spain). Avian Dis., 30, 416-420.

Castleman, W.L. (1984): Alterations in pulmonary ultrastructure and morphometric parameters induced by parainfluenza (Sendai) virus in rats during postnatal growth. Am. J. Path., 114, 322. 
Cheville, N.F and Beard, C.W. (1972): Cytopathology of Newcastle disease. Lab. Invest., 27, 129 .

Christopher, D.S.; Chennakesavalu, M. and Rajendran, M.P. (1993): Incidence of encephalomyelitis in pigeons in Tamil Nadu. Indian Vet. J., 70, 365-366.

Donelly, W.H. and Yunis, E.J. (1971): The morphogenesis of virulent Newcastle disease virus in the chick embryo. An ultrastructural study. Am. J. Path., 62, 87.

Duchatel, J.P., Flore, P.H.; Hermann, W. and Vindevogel, H. (1992): Efficacy of an inactivated aqueous-suspension Ncwcastle disease virus vaccine against paramyxovirus type 1 infection in young pigcons with varying amounts of maternal antibody. Avian pathol., 21, 321-325.

El-Mubarak, A.K.; Llzein, E.E.A.; Elgasim, A.I.A.; Abu-Elzein, E.M.E. and Abu-Elgasim, A.I. (1990): Note on the pathology of experimental infection of pigeons by the pigeon paramyxovirosis typc 1 (PPMV-1). Revue-d'Elevage-et-deMedecine-Veterinarie-des-Pags-Tropicaux, 43, 441-444.

El-Sisi, M.A.; Shakal, M., Aly, 1. and Abou Hashem, N. (1995): Pathogenicity of recent isolates of pigeon paramyxovirus in pigeon in Egypt. Vet. Med. J., Giza, 43: 2, 207-212.

Finch, J.T. and Gibbs, A.J. (1970): Observations on the structure of the nucleocapsids of some paramyxoviruses. J. Gen. Virol., 6, 141150.

Grimley, P.M. and Friedman, R.M. (1970): Developments of Scmliki Forest virus in mouse brain : an electron microscopic study. Expl. Molec. Path, 12, 1 .

Gurkirpal-Singh (1993): Biological properties of avian paramyxovirus type 1 isolated from pigeon. Indian $J$. of Comparative Microbiology, immunology and Infections Diseases, $14: 34-35$.

Hamson, J.; Lowes, $N$., Chalmers, $G$. and Mclntosh, D. (1989): Paramyxovirus infection in pigeons. Canadian Vet. J., 12, 970.

Holmes, I.H.; Work, M.C. and Warburton, M.F. (1969): Is rubella an arbovirus? II. Ultrastructural morphology and development. Virology, 37, 15 .

Ibrahim, R.S.; Moustafa, F.A. and Mubarak, M. (2000): Paramyxovirus infection in pigeons. Assiut Vet. Med. J., 44, 206-222. 
Johannessen, J, (1978): Instruction and techniques. In:Flectron Microscopy in Human Medicine, Vol.1.Mcgraw -Hill international book company

Johnston, K.M. and Key, D.W. (1992): Paramyxovirus-1 in feral pigeons (Columbia livia) in Ontario. Canadian Vet. J., 33, 796-800

Kaleta, E.F.: Alexander: D.J. and Russell. P.II. (1985): The first isolation of the avian PMV-1 virus responsible for the current panzootic in pigeons. Avian Pathology, 14, 553-557.

Kosters, J.; Schneeganss, D. and Korbel, R. (1992): Lxperience with immunization against pigeon paramyxovirus in Germany. Praktische Tierarzt, 73, 861-864.

Lancaster, J.E. and Alexander, D.J. (1975): Newcastle disease : virus and spread. Monogr. No. 11, P. 26. Can. Dept. Agric., Ottawa.

Mangat, A.P.S.; Singh, $G$ and Gill, B.S. (1988): An outbreak of paramyxovirus encephalomyclitis in racing pigeons in India. Vet. Rec., 123, 496

Mclean, A.M. and Doane, F.W. (1971): The morphogenesis and cytopathology of bovine parainlluenza typc 3 virus. J. Gen Virol., 12, 271-279

Mohammed, MA. Sokkar, S.M and Tantawi, H. (1978): Contagious paralysis of pigeons. Avian Pathol. 7,637-643.

Pennycott. T:W. (1994): Avian Paramyxovirus type 1 in feral pigeons. Vet. Rec., $134: 21,260$.

Russell, P.H. and Alexander, D.J. (1983): Antigenic variation of Newcastlc disease virus strain detected by monoclonal antibodies. Arch. Virol., $75: 243-245$.

Seto, J.T.; Wahn, K and Becht, H. (1980): Electron microscope study of cultured cclls of the CAM infected with representative paramyxoviruses. Arch. Virol, $65,247-255$.

Shakal, M.A. (1989): 7ur Isolierung und Charakterisierung von aviaeren paramyxovirus stammen aud degypishenund deutschen Haustauben (Columba Livia Gmel. 1789 Var. Donestica) unter verwendung von permanentzellinen. $P h$. D. Thesis, Tieraerztl. Fakultaet. Ludwig - Maximilians Universtaet, Muenchen, Germany.

Tontawi HU and Hassan, F. (1982). Pigeon herpes encephalomyelitis virus in Egypt. Trop. Anim. Ith Proc., 14, $20-22$ 
Tantawi, H.H.; Al Falluji, M.M. and Al Sheikhly, F. (1979): Viral encephalomyelitis of pigeons: identification and characterization of the virus. Avian Dis., 23,785-793.

Whitefield, S.G., Murphy, F.A. and Sudia, W.D. (1971): Eastern equine cncephalomyelitis virus : An electron microscopic study of Aedes triseriatus (Say) salivary gland infection. Virology, 43, 110.

Wilczynski, S.P. Cook, M.L. and Stevens, J.G. (1977): Newcastle disease as a model for paramyxovirus induced neurologic syndromes. Am. J. Path, 89, 649-666.

Wilson, G.W.C. (I986): Newcastle disease and paramyxovirus 1 of pigeons in the European community. World Poullry Sci. J., 42, 143-153.

Zlotnik, I. and Harris, W.J. (1970): The changes in cell organelles of neurons in the brain of adult mice and hamesters during Semliki forest virus and louping ill encephalitis. Br.J. Exp. Path., 51, 37. 


\section{LEGENDS FOR FIGURES}

Fig. 1: Brain of an infected pigeon showing neuronal degenerative changes, including cell swelling, chromatolysis (arrow) and peripheralization of nucleus. Note the pericellular edema (arrowhead). HE. X160

Fig. 2: Diffuse microgliosis in the brain tissue of an infected pigeon. The microglia cells are mainly gathered nearby the degenerated neurons. HE. X160

Fig. 3: Satellitosis and neuronophagia (arrow) in the brain of an infected pigeon. HE. $X 160$

Fig. 4: Demyelination in the brain stem of an infected pigeon, The demyelinating process gives the brain tissue a spongy status. HE. X 160

Fig. 5: Interstitial lymphoid cell infiltration in the myocardium of an infected pigeon. The infiltrated area reveals myodegeneration and myolysis. MR. X 160

Fig. 6: Kidney of an infected pigeon showing interstitial lymphoid cell infiltration. HE. X 160

Fig. 7: Transmission electron micrograph showing mature viral particle (arrow) in the cytoplasm of a neuronal cell in the cerebral gray matter of an infected pigeon. X 27420

Fig. 8: Higher magnification for Fig, (7). Note the filamentous nuclear core (nucleocapsids) (arrow) and the external enveloping membranes (arrowhead). Transmission electron micrograph. X 42400

Fig. 9: Rounded viral particles (arrows) in the cytoplasm of a neuronal cell. The particles possess distinct enveloping membrane and surface spikes. The mitochondria (m) are swollen. Cerebral gray matter of an infected pigeon. Transmission electron micrograph. X 27500

Fig. 10: Budding viral forms (arrow) in close association to the infected neuronal cells. Certain segment of the cell membrane (arrowhead) is of higher electron density and has spikes on its outer surface. Transmission electron micrograph.X 26200. 


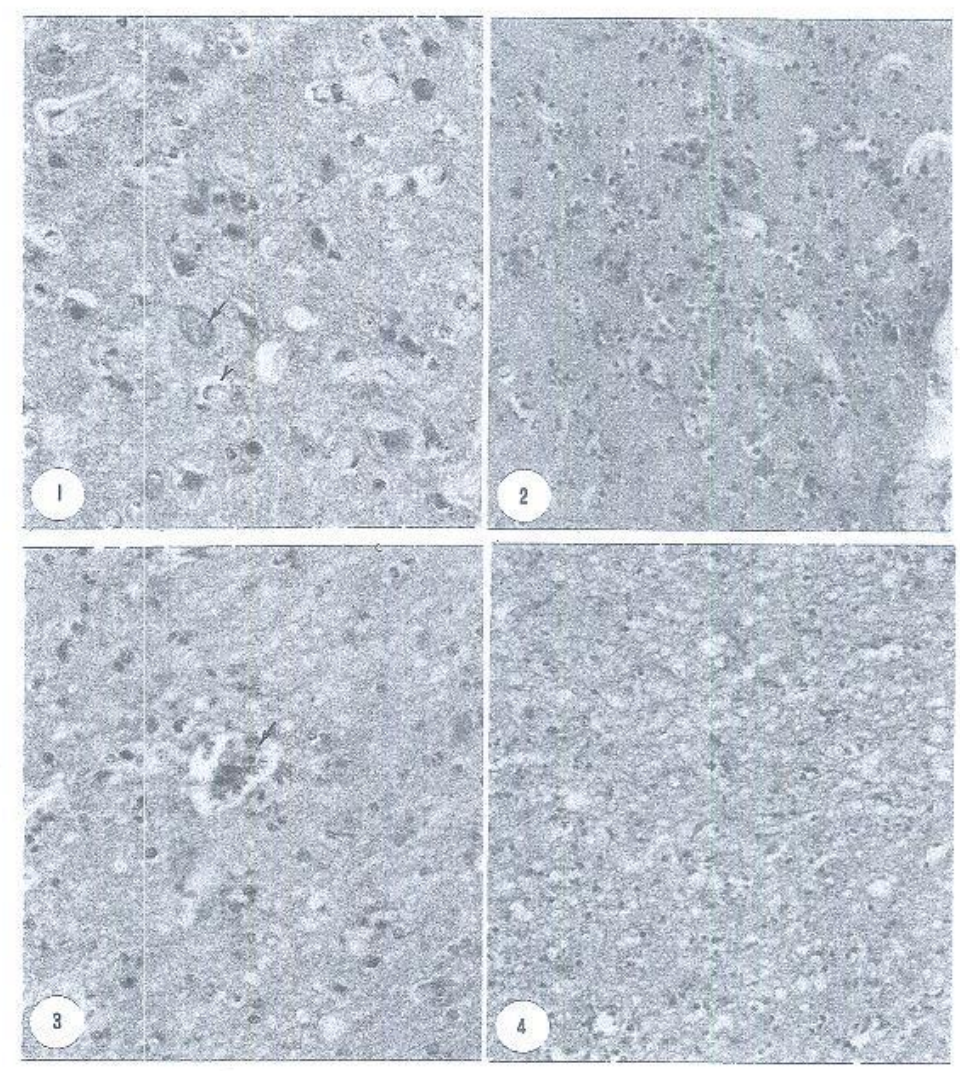



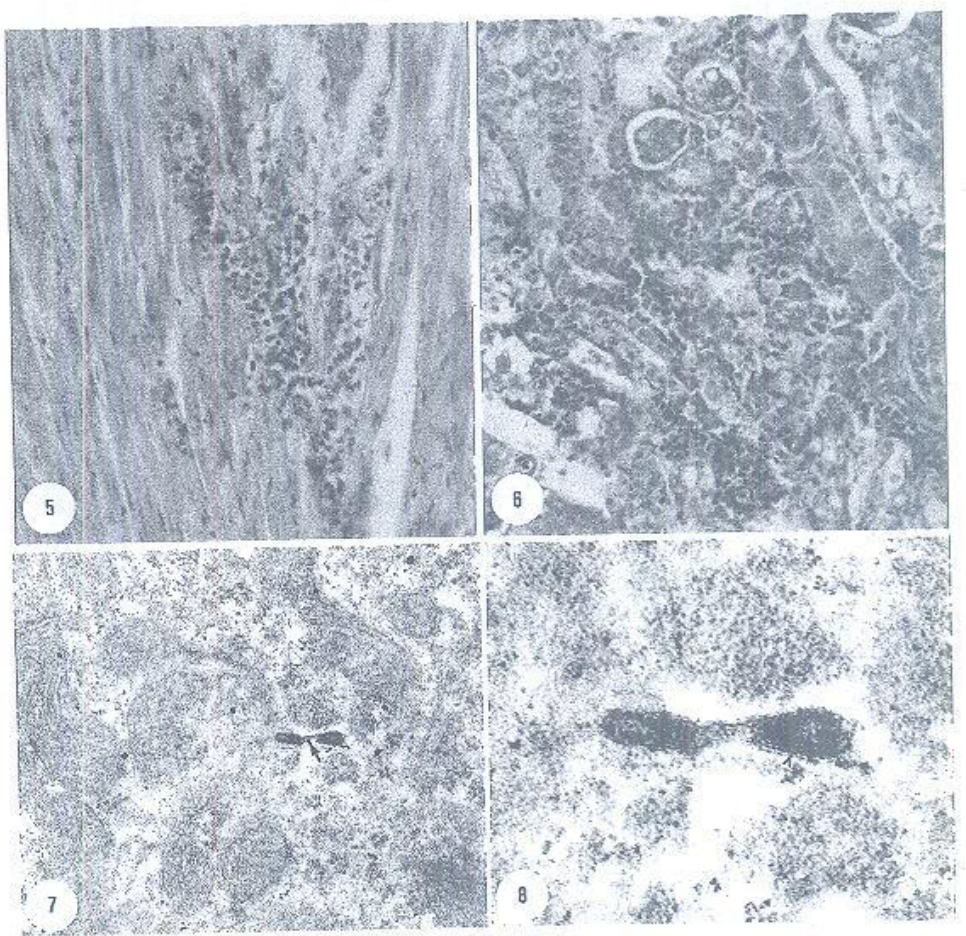


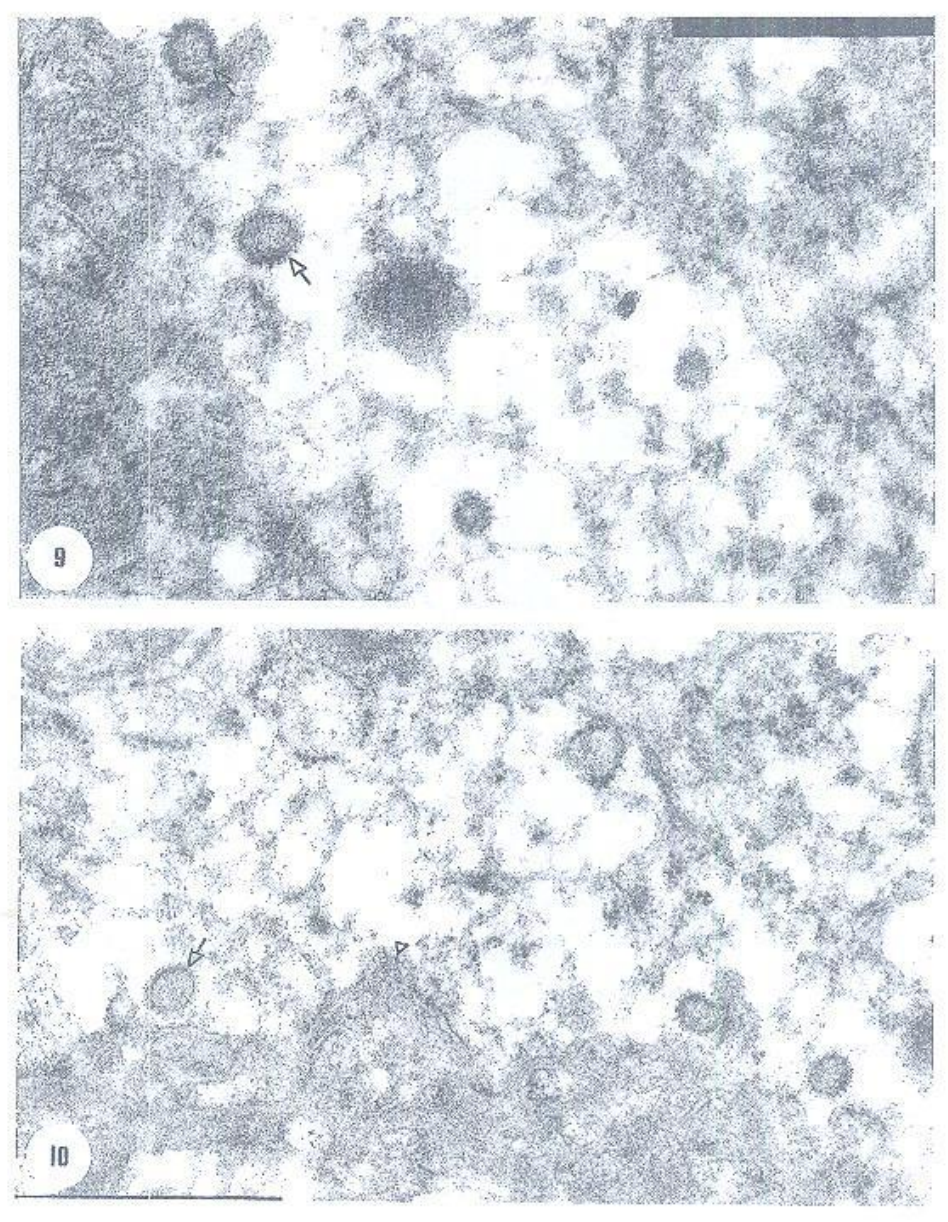

